\title{
Author Correction: Cell non-autonomy amplifies disruption of neurulation by mosaic Vang/2 deletion in mice
}

\author{
Gabriel L. Galea (1), Eirini Maniou (D), Timothy J. Edwards, Abigail R. Marshall, loakeim Ampartzidis (1), \\ Nicholas D. E. Greene (D) \& Andrew J. Copp (1)
}

Correction to: Nature Communications https://doi.org/10.1038/s41467-021-21372-4, published online 19 February 2021.

The original version of this Article contained an error in the Code availability statement, which omitted a link to the in-house Fiji macro. The Code availability statement should read:

"Cellpose processing is available on GitHub https:/github.com/timjedwar/Vangl2-cell-morpho.112. The in-house Fiji macro developed to identify and extract the surface of 3D structures is available from https://github.com/DaleMoulding/Fiji-Macros and related resources are available from the corresponding author on reasonable request or previously published ${ }^{14}$."

This has been corrected in both the PDF and HTML versions of the Article.

Published online: 28 May 2021

\begin{abstract}
(c) Open Access This article is licensed under a Creative Commons Attribution 4.0 International License, which permits use, sharing, adaptation, distribution and reproduction in any medium or format, as long as you give appropriate credit to the original author(s) and the source, provide a link to the Creative Commons license, and indicate if changes were made. The images or other third party material in this article are included in the article's Creative Commons license, unless indicated otherwise in a credit line to the material. If material is not included in the article's Creative Commons license and your intended use is not permitted by statutory regulation or exceeds the permitted use, you will need to obtain permission directly from the copyright holder. To view a copy of this license, visit http://creativecommons.org/licenses/by/4.0/.
\end{abstract}

(c) The Author(s) 2021 